\title{
ROLE OF THE EUROPEAN FISHERY FUND SUPPORT IN THE DEVELOPMENT OF THE LATVIAN COSTAL AREAS
}

\author{
Armands Puzulis, Armands Vēveris \\ Institute of Agricultural Resources and Economics, Latvia \\ armands.puzulis@arei.lv
}

\begin{abstract}
Purpose of the paper is to assess contribution of the European Fishery Fund (EFF) and European Maritime and Fisheries Fund (EMFF) in the development of coastal areas. The article reviews particulars of implementation of the Fishery Funds in various planning periods, in more detail analysing the implementation impact in the period of 20142020, based on analysis of the needs, goals and projects of the current period. Even though the European Fishery Fund (EFF) in Latvia is being implemented since 2007, there is a lack of scientific publications on its impact on the coastal development.

EMFF for the period 2013-2020 has a dual role in the development of coastal areas - as a development tool of the fishery sector and as a development tool of communities in the fishery areas. It is implemented by using communityled local development (CLLD/LEADER) approach. In case of Latvia, a multi-fund approach - EFF/EMFF and European Agricultural Fund for Rural Development (EAFRD) is already being used for two planning periods.

We conclude that the impact of EFF/EMFF on the development of coastal areas is more directed at development of infrastructure of the coastal communities but is less engaged in the fishery development matters - accordingly increasing other activities and preserving historic and cultural heritage for development of tourism and place of residence in the coastal area in interaction and in addition to EAFRD rural development measures of the coastal areas. Key words: EMFF, CLLD, coastal areas, multi-fond.
\end{abstract}

\section{Introduction}

Subject is important as contributions of the aforementioned fund in terms of money are rather significant: the planned EMFF public funding in Latvia for the period of 2014-2020 is EUR 140 million, but together with the state funding - EUR 182.7 million. Contribution of EMFF in the development of coastal communities is mostly related to measures of the 4 th priority implemented by CLLD. Public funding in the amount of 15 million EUR is provided for them.

CLLD approach prescribes to establish the areas important for the fishery whereto drafting of the local development strategies is applicable. These strategies are created by the Fisheries Local Action Groups (FLAG) or simply LAGs from the period of 20132020 , with a participation of public, local government and business representatives in the decision-making institutions, respecting local needs and planning and implementing support measures carried out in cooperation between the institutions. Support is given to the fishery sector and territorial communities related to fishery. CLLD in the EU Common Fishery Policy was taken over from the EAFRD funded LEADER approach of the Common Agricultural Policy (Ex-post evaluation ..., 2017). During the period of 2014-2020, the fishery measures are implemented either separately (single-fund approach) or jointly with other funds (multi-fund approach). Integration of both funds mostly leaves an impact on development of communities and especially on formation, development and diversification of small companies, as well as on creation of jobs, where Latvia has a positive experience (Scoping study ..., 2015). Additionally, the impact is directed at life quality, identity, improvement of the living environment of the coastal communities which may not be assessed in a short term (Ex-post evaluation ..., 2017).

A sectoral policy was created in the scope of the fishery fund, which is integrated in the development of local areas (Phillipson \& Symes, 2015). Such approach makes you ask a question, how effective it was for the sector itself and for the territorial community. Several authors indicate that initially innovative approach in the development of the fishery areas has been forgotten, partially relating it to the EU framework, which reduces significance of the social role, contradicts with neoliberal approach and application of sustainability principles in specific areas, affecting viability of the fishery community (Symes \& Phillipson, 2009).

In practice, there is a transfer from restriction of fishing to fishing in inshore waters, diversification measures, support to maritime communities (Bartłomiejski, 2011). It is noted that communities where a decisive role is played by the small-sized coastal fishing, great emphasis is placed on solutions based on local knowledge, considering ecological, economic, social and management aspects (Symes, Phillipson, \& Salmi, 2015). Return to initial LEADER principles is also on the agenda of the next programming period after 2020 (Beyond 2020 ..., 2017).

Even though CLLD measures are being implemented in a comparatively short period of time, there are publications, where their efficiency has been reviewed (for example, Capgemini Consulting, 2014; Symes, Phillipson, \& Salmi, 2015; Walle et al., 2015). At the same time, this subject has not been sufficiently viewed in the scientific literature of Latvia. Several 
studies concerning EFF and Operational Programme for the Latvian fisheries sector (OP 2007-2013) implementation are available (please refer to Benga, 2014; Baltic Consulting ..., 2011, Justification ..., 2013; Analysis ..., 2012), which partially review areas significant for fisheries (ASF) coastal community development matters.

Purpose of the paper is to assess the contribution of EMFF in the development of coastal areas. The following objectives have been set for reaching the goal of the paper: to assess the current scientific studies on the development of coastal areas in connection with EFF/EMFF, analyse implementation specifics of $\mathrm{EFF} / \mathrm{EMFF}$ in the development context of the Latvian coastal areas, evaluate costal support measures in the period of 2014-2020 and their provisional results.

The hypothesis of the article - the impact of the fishery fund is mostly directed at compensating activities for reduction of the fishery sector's role, which jointly with EAFRD form a supplementing effect for the development of coastal areas.

\section{Materials and Methods}

Foreign and Latvian scientific studies, European Commission materials and other special literature has been used for the preparation of the article. Operational Programme for the Development of Fisheries 20142020 (OP 2014-2020), strategies developed by the LAGs, and, laws and regulations of Latvia and the European Union have been reviewed. A combination of quantitative and qualitative analysis methods has been used in the paper. A context analysis method was used to evaluate LAGs needs. In order to specify conclusions on EMFF impacts, a survey of LAGs administrative managers was conducted in 2018, consultations organized, and partially structured interviews with the sector specialists, LAGs and fishermen representatives were carried out. Numerical materials were gathered by using the Rural Support Service (RSS) IS information for a time period up to 2019. Considering the peculiarities for implementation of the programme for 2014-2020, the project application (planned) data was used for the analysis.

\section{Results and Discussion}

Financing of the fishery funds in Latvia is available since 2004. Initially (2004-2006) the EU available funding of the Financial Instrument for Fisheries Guidance (FIFG) was more than EUR 24 million, and more than 380 projects were supported.

The goal of the EFF for 2007-2013 was to facilitate sustainable development in fishery sector and areas important for the fishery, increasing competitiveness of the sector and balancing fishing capacity with the available fish resources. Total public funding for $\mathrm{OP}$ 2007-2013 exceeded EUR 166 million, including from EFF in the amount of EUR 125 million. The 4th priority direction 'Sustainable development of the areas important for fisheries' was intended for improvement of life quality in the areas important for fisheries and increasing their attractiveness, using CLLD approach. Creation of small fishery and tourism infrastructure objects, an offer of related services, diversification of economic activity, and restoration and development of historic fishermen villages was supported (Operational Program ..., 2007).

In accordance with OP 2007-2013, areas significant for fisheries (ASF) based on the total number of persons employed in the fisheries in the country and a total number of companies in the country was established. ASF encompassed 24 Fishery local action groups (FLAG). They incorporated both coastal and inland areas. ASF in 2007-2013 were directed at updating, development and implementation of the measures supported by the Rural Development Programme (RDP), paying very little attention to the problems of the fishery (Study on the implementation ..., 2014). Majority of the projects were related to the improvement of the living environment and not specifically fishery, infrastructure (Analysis ..., 2012). This is confirmed by an allocation of funding in the FLAG strategies among priorities, where an activity 'Restoration and development of the villages where fishery activities are carried out' is dominating (Baltic Consulting, 2011). Allocation of funding in the coastal FLAG projects among activities is $73 \%$ for the restoration and development of villages, $25 \%$ - for fishery and tourism infrastructure and services and $2 \%$ for economic restructuring and diversification (Benga, 2014). In addition, it was established in the studies that 14 of 24 FLAGs are located in inland territories without industrial fishing (Walle, 2017).

Coastal areas were established in a strip of $15 \mathrm{~km}$ from the coast of the sea where additional funding for restoration of the village infrastructure was planned. Coastal ASF support was more directed at small coastal fishermen and processors of local produce. Support to coastal small volume fishing in the period of 2007 2013 in Latvia was, however, weakly pronounced and formed just $2 \%$ of the total number of OP 2007-2013 $4^{\text {th }}$ axis projects (Walle, 2017).

It was partially determined by the peculiarities of the programme itself - an amount of EFF funding was too small for the large companies, while access to these resources by small companies and home producers was complicated due to various reasons related to fulfilment of strict requirements and necessity for cofunding (Analysis ..., 2012).

EFF and EAFRD were implemented by a partial multi-fund approach, which was partially started to be implemented already in the period of 2007-2013. It means that a single strategy and different action plans 
were in force, and different executive institutions with an administration could exist. Fund recording was strictly separated (Benga, 2016).

Different designations are used, i.e. LEADER RDP, CLLD - for OP both periods. There is a uniform LAG, including both EMFF and EAFRD measures, a single management - partnership - deciding authority and executive institution (administration), a uniform strategy, encompassing two funds, while CLLD strategy actions are separated for each fund. Such structure allows optimizing administrative costs.

The second role of the Multi-funds may be related to concentration of means of two funds in ASF, which makes us to ask a question regarding a risk of the fund overlapping, which is confirmed by the similar potential activities of EFF/EMFF and EAFRD. There are contradictions between the development of the sector and location. The sector is exterritorial and related to all EFF/EMFF priorities; the development of the location may be projected in the EMFF 4th priority. Similarly, it pertains to EAFRD concerning ASF. It makes us ask a question how EMFF integrates into this system, and to whom and how much it gives to the local community and the sector.

In the regulatory framework, funds are partially separated, for example, in respect of development of strategies, while they are common for the cooperation projects, and separated in respect of implementation and activation of strategies. It must be noted that the measures of public activation are implemented, using EAFRD funding. The requirements in the uniform framework (Cabinet Regulations) are also made in accordance with the relevant EAFRD and EMFF funds. Each fund has a different strategyimplementation framework.

In the period 2014-2020, ASF determination principle was changed based on deficiencies of the previous period, establishing that it shall contain only the areas of the coastal administrative units - cities and parishes bordering the sea, except for Riga, but including 3 large cities - Liepaja, Jurmala and Ventspils. EMFF measures are implemented by 6 LAGs bordering sea. The length of the coastal area and several persons employed in fishery were selected as the criteria for establishing of ASF and allocation of funding (Justification ..., 2013). It means that 6 LAGs at the costal ASF may receive both EMFF and EAFRD funding (except in the large cities), while only RDP EAFRD funding is available in the LAGs inland areas. Funding of both funds is different in various ASFs, while EMFF funding has much more importance in coastal area, which is determined by historically and geographically established comparatively smaller employment of the coastal area residents in agriculture, closer connection of residents to fishery (Figure 1).

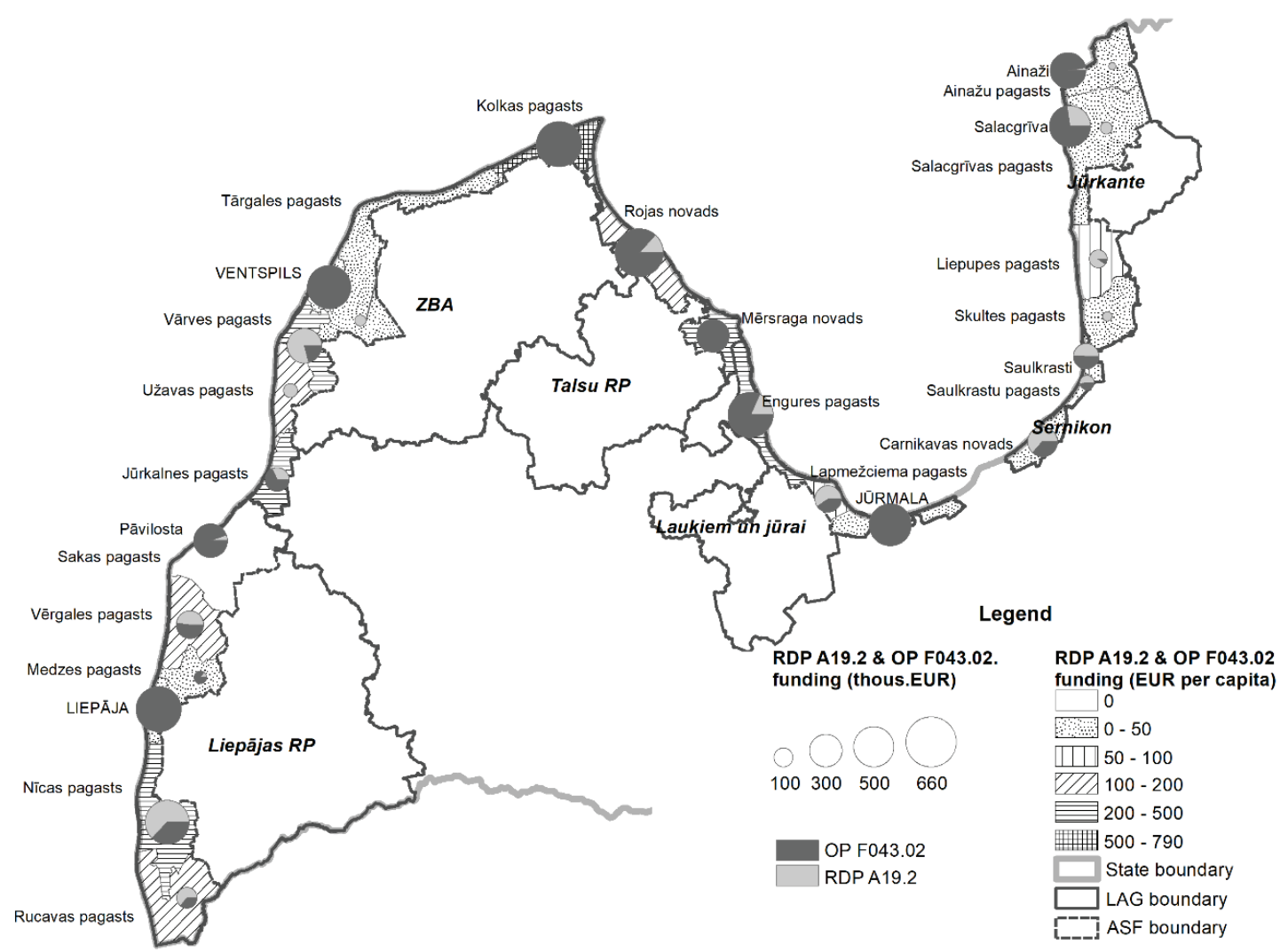

Figure 1. Public funding to ASF of the projects being implemented in OP 2014-2020 and RDP measures. Source: Authors calculation based on RSS IS. 
Analysis of the needs defined in the LAGs strategies is based on the strengths and weaknesses of the SWOT analysis and sections of the strategy needs, as well as a LAGs manager survey. Context analysis allows highlighting the following common needs: improvement of infrastructure, knowledge, natural values, heritage, services, business, whereto needs for jobs and labour force are strongly related. Demographic and population problems are also important. Knowledge has been mentioned both with strengths and weaknesses. LAGs indicate in strategies the communication problems between a local government and NGOs, lack of leaders, motivation, limited opportunities for the life-long education and youth development, business knowledge. Interest in studying, trade skills, opportunities for interest education, competence in cultural area, creative activity of youth is at the same time mentioned as an advantage.

The needs identified in the sections of needs of the LAGs strategies are mainly related to business and companies, innovations, services, tourism. Jobs, education, use of local resources are emphasized relatively less. The aforementioned needs may be integrated and understood as parts of other needs; the analysis therefore does not allow making precise conclusions on the LAGs needs (Figure 2).

In general, needs are subjected to terms of the funding, appropriate EMFF and EAFRD measures are not always separated in the strategies.

Needs on the level of goals appear in general manner and are not always related to a specific fund. On the level of actions, LAGs strategies separate funding of the funds. In 6 LAGs strategies, 18 actions pertain to EMFF. Actions expressly include fishery and economic diversification, use of infrastructure and natural resources and reduction of climate changes, which in general conforms to defined needs. Results of surveys allow concluding that comparatively larger contribution of projects is in development of infrastructure, facilitation of public activities and LAGs operation. In addition, the greatest effect is indicated in the aspects attributed to maintaining of population (jobs, social environment and services). In turn, the lowest rated project contribution pertains to inclusion of low-income individuals and reduction of poverty, as well as business development, which only partially conforms to the needs included and actions planned in the strategies.

The problem is in linking with specific needs, and it means a gap between defining the needs expressed by LAGs communities and the funding linked to administrative process - allocation of funding between actions, rounds of the project tenders and linking thereof to OP 2014-2020 activities. Actions of LAGs strategies are not always able to depict a complete spectrum of needs, but the strategy development and implementation animation procedures not always can address the actors and inform them on opportunities provided by the projects. As the result, for example, activities directed at joint projects and replacement of the main stationary engine are not applied in the projects, even though they are very topical for the fishermen.

The most important OP 2014-2020 measure which is intended to facilitate coastal development is F43.02 measure 'Community-led implementation of local development strategies'. An amount of EUR 14.7 million is planned for it in the entire period.

103 projects are in the implementation process in the measure F43.02 as of 08.01.2019 (status-approved, monitoring has been initiated), from which $56 \%$ are

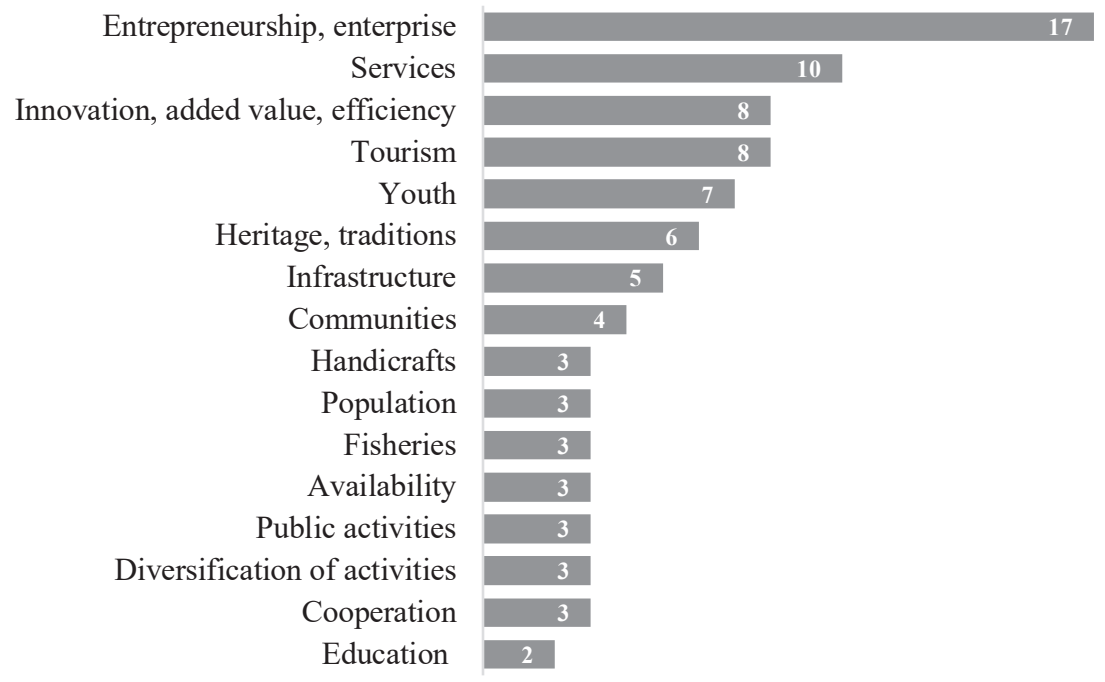

Figure 2. Proportion of key words of the needs defined in coastal LAG strategies.

Source: Created by authors, based on LAG strategies. 


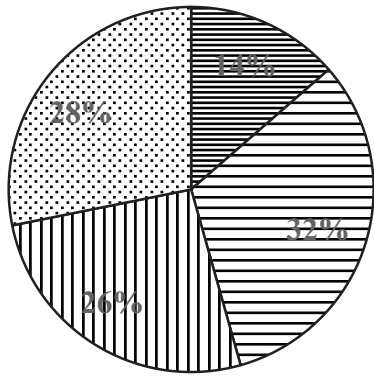

$\begin{array}{ll}\text { 目fisheries } & \boxminus \text { diversification } \\ \text { ■ environment } & \square \text { cultural heritage }\end{array}$

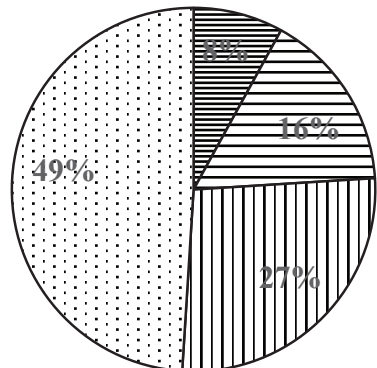

目 fisheries $\quad$ diversification

Denvironment $\square$ cultural heritage

Figure 3. A number of projects in F043.02 measure of the OP 2014-2020 and public funding (according to application data) in the measure.

Source: Compilation by authors from RDS IS.

completed. The total disbursed amount is EUR 3.5 million, which is $24 \%$ of the total public funding amount of the measure. Public funding for the projects in the implementation process forms EUR 7.3 million, which is half of the planned amount in this measure.

Despite the fact that facilitation of economic activity has been recognized as the most important need in the LAGs strategies, the majority of approved projects is related to environmental and climate goals or preservation of cultural capital. Assessing the measure based on the number of projects in the measure activities, we can see domination of diversification projects (mostly for development of tourism), contrary to the investment in the projects directly related to fishery. More than half $(54 \%)$ of the projects are directed at public activities, which is an investment in the development of ASF communities. Environmental and climate project goals mostly include improvement of beaches, tourism infrastructure (creation of nature trails, construction of access roads and parking lots) and similar activities. A significant part of the projects is related to preservation of fishing cultural heritage in the coastal villages. The main directions of operation in this direction: renovation of buildings and structures (gathering centres, churches and other historic architecture), renovation of fishing boats and cutters, creation of parking lots and introduction of infrastructure. Several projects are related to preservation of the Livs cultural heritage. Only 10\% of all projects have relation to coastal fishing. It may be seen from the above that support to coastal areas mostly facilitates the local infrastructure development (including, to a great extent, directed at tourism), but the impact on development of local fishing is rather small. There is in general a comparatively small impact also on facilitation of economics (Figure 3 ).

If the volume of eligible costs is compared in activities, they differ even more. Costs of the projects related to fishery form $8 \%$ of the total costs of the projects in implementation process, and diversification projects form $16 \%$. At the same time, projects of public nature directed at the environmental and cultural objects form $76 \%$ of the total project public funding. Thus, the measure makes the main contribution in the development of ASF communities, less in the fishery (Figure 3). Environmental and cultural projects indirectly can also be related to facilitation of economics, for example, tourists are attracted by creating recreational place or a museum exhibition.

CLLD approach is directed at support to small business, which is confirmed also by the restrictions of the project funding. Micro companies (up to 9 employees) form more than $90 \%$ of the number in fishery and aquaculture and half of the fish processing companies. In accordance with the information provided in LAG interviews, they often have problems with co-funding of projects, but the largest companies select to participate in the 5 th priority measures with larger funding and shorter time for approval of projects. It partially explains small interest in fish processing projects in the 4th priority. Additionally, micro companies are often not ready to handle administrative matters - accounting, preparation of projects, take responsibility for progress of the projects. It requires additional investments and individual approaches in the LAGs work with the fishermen for their activation.

Taking into account the goals of the social and territorial cohesion, the main indicator by which the project results are measured is a number of newly created jobs. This is the sole indicator selected by Latvia for evaluation of OP 2014-2020 4th priority outcome. In accordance with the plan, 70 new jobs are planned to be created in the coastal areas with the help of EMFF. The projects currently being implemented prescribe for creation of 63 jobs, including in fishery sector -18 , outside the sector -45 . The jobs are planned mostly in the sectors related to fishery - in processing of fish products, services, tourism and trade. New jobs 
are not planned directly in fishing and aquaculture, yet in accordance with the project applications, $29 \%$ of new jobs indicatively can be related to fishery, which includes projects in all fishing and aquaculture stages from acquisition to sale. $71 \%$ of all planned jobs are mostly related to tourism and services. We may conclude from this that contribution of the measure in creation of jobs may be related mostly to economic diversification but not to fishery. It must be noted that creation of new jobs in the project applications is not a mandatory precondition; therefore, only $1 / 3$ of the total number of projects plan to create them. In addition, almost all newly created jobs pertain to the projects of economic nature.

The involvement of youth and life-long learning has been emphasized in the LAGs strategies, the EU regulation and national framework, while insufficiently prescribed in the LAGs strategies actions and projects. It is recognized in the interviews with the LAGs and Latvian fisheries network that interest currently is rather small. Fishery has large initial investments which interfere with interest in this area. There is an opportunity to inherit infrastructure or to purchase it from the existing fishermen. It, in general, reduces further sustainability of development in the local ASFs.

\section{Conclusions}

1. Publications on development of coastal fishery areas allow concluding that the impact of the Fishery Fund is mostly directed at compensating activities for reduction of the fishery sector's role.

2. Experience of Latvia points at investments mostly for preservation of coastal area infrastructure and cultural heritage, but less for strengthening the role of fishery in local economics.
3. Use of the multi-fund approach may be rated as supplemental to development of coastal areas, allowing using of available funding in a more rational manner.

4. Experience of two periods in the use of EMFF in facilitation of coastal development allows forming a more comprehensive view at the community development matters, an opportunity to learn and improve the LAGs strategies and implementation tools.

5. Even though the LAGs strategies have a pronounced need for the business support and thus also for jobs, it is to a smaller extent indicated in the projects, which attests to failure to link identified needs to the implementation goals and actions of the LAGs strategies. If we evaluate results of the strategies, it is useful to look at it not only in respect of the goals and actions but also in respect of the needs.

6. CLLD is a tool for development of small fisheries which is not always indicated in the projects. It requires more involvement of LAGs in the communication process, on one hand, and simplification of requirements, on the other hand.

7. EMFF gives a significant contribution to development of ASF communities, especially in infrastructure.

Even though neither OP nor LAGs strategies have clearly defined allocation among activities, the project analysis of 2014-2020 period allows concluding that absolute majority is directed at infrastructure and equipment projects for the public benefit community, and very little at fishery, creation of new jobs in the sector, which confirms the initial hypothesis.

\section{References}

1. Baltic Consulting. (2011). Rīcības programmas 'Eiropas Zivsaimniecības fonda atbalsta ieviešanai Latvijā 2007. - 2013. gadam Vidus termiņa (Interim) novērtējums’. Ziņojums. (Operational program of Implementation of the European Fisheries Fund support in Latvia 2007-2013. Interim assessment report). (in Latvian)

2. Bartłomiejski, R. (2011). Fisheries Local Action Groups: A New Theme for Researching Maritime Communities. Roczniki Socjologii Morskiej. Annuals of Marine Sociology, XX.

3. Benga, E. (2014). Zvejniecības attīstība Baltijas jūras un Rīgas jūras līča piekrastes joslā (piekrastes zveja). Atskaite. (Fishing Development in the Coastal Zone of the Baltic Sea and the Gulf of Riga (Coastal Fishing. Report)) LVAEI. (in Latvian)

4. Benga, E. (2016). Ziņojums. Lauku attīstības programma 2007-2013. Ex-post novērtējums. (Rural Development Program 2007-2013. Ex-post evaluation. Report) AREI. (in Latvian)

5. Beyond 2020: Supporting Europe's Coastal Communities. Conclusions of the EMFF stakeholder conference. Tallinn, 12-13 OCT 2017. Retrieved January 12, 2019, from http://www.emff-now-and-then. eu/documents/DG-MARE-Conclusions-Conference-A4-03.pdf.

6. Capgemini Consulting. (2014). Study on the Implementation of Axis 4 of the European Fisheries Fund (Brussels: European Commission, DG MARE). Retrieved December 12, 2017, from https://ec.europa.eu/ fisheries/sites/fisheries/files/axis-4-final-report_en.pdf.

7. Eiropas Zivsaimniecības Fonda (EZF) līizfinansētā Rīcības programma EZF atbalsta ieviešanai Latvijā (2007.-2013.g.). (2007). (Operational Program for the Implementation of the EFF Support in Latvia (2007-2013) co-financed by the European Fisheries Fund (EFF)) Brisele, MEMO/07/613. (in Latvian) 
8. Ex-post evaluation of the European Fisheries Fund 2007-2013. (2017). Final Report. MARE/2011/01, EU. Retrieved March 6, 2019, from https:/publications.europa.eu/en/publication-detail/-/publication/ f0ab224d-f34c-11e6-8a35-01aa75ed71a1/language-en.

9. Phillipson, J., \& Symes, D. (2015). Finding a middle way to develop Europe's fisheries dependent areas: The role of Fisheries Local Action Groups. Sociologia Ruralis, 55(3), 343-359. DOI: 10.1111/soru.12098.

10. Scoping study for the use of financial instruments under the EMFF and related advisory support activities. (2015). Final Report. European Commission.

11. Study on the implementation of Axis 4 of the European Fisheries Fund. (2014). Final report. MARE/2011/01.

12. Symes, D., \& Phillipson, J. (2009). Whatever became of social objectives in fisheries policy? Fisheries Research, 95(1), 1-5. DOI: 10.1016/j.fishres.2008.08.001.

13. Symes, D., Phillipson, J., \& Salmi, P. (2015). Europe's Coastal Fisheries: Instability and the Impacts of Fisheries Policy. Sociologia Ruralis, 55(3), 245-257. DOI: 10.1111/soru.12096.

14. Walle, G. (2017). Assessment of Fisheries Local Action groups support to Small Scale Coastal fisheries in Europe. Technical Report. DOI: 10.13140/RG.2.2.21228.05763.

15. Walle, G., Gomes da Silva, S., O’Hara, E., \& Soto, P. (2015). Achieving Sustainable Development of Local Fishing Interests: The Case of Pays d'Auray flag. Sociologia Ruralis, 55(3), 360-377. DOI: 10.1111/ soru. 12097.

16. ZVRG stratēgiju un ieviesto projektu ekonomiskās dzīvotspējas analīze. (2012). EZF Rīcības Programma 2007-2013. (Analysis of economic viability of FLAG strategies and projects implemented). LVAEI. (in Latvian)

17. ZVRG teritoriju kritēriju pamatojums. (2013). Atskaite. EZF Rīcības Programma 2007-2013 (Analysis of economic viability of FLAG strategies and projects implemented. EFF Action Program 2007-2013). (Justification of criteria for FLAG territories. Report. EFF Action Program 2007-2013). (in Latvian) 